\title{
Media Pembelajaran Berbasis Multimedia Interaktif untuk Meningkatkan Pemahaman Konsep Mahasiswa
}

\author{
Inung Diah Kurniawati ${ }^{1}$ dan Sekreningsih Nita ${ }^{2}$ \\ Dosen Teknik Informatika, Fakultas Teknik, Universitas PGRI Madiun \\ ${ }^{1}$ inungdiah@unipma.ac.id dan ²ben_nita2002@yahoo.com
}

\begin{abstract}
Abstrak
Fisika merupakan suatu cabang ilmu pengetahuan sains. Fisika mempelajari tentang sesuatu yang konkret dan dapat dibuktikan secara matematis. Tidak sedikit dari mahasiswa yang beranggapan bahwa mata kuliah fisika itu sulit dan menakutkan. Oleh karena itu, anggapan negatif ini perlu dihilangkan dan perlu diubah pola pikir mahasiswa tentang anggapan negatif ini. Walaupun selama ini pembelajaran mata kuliah fisika sudah memanfaatkan teknologi, tetapi belum pemanfaatan ini belum optimal. Untuk itu, diperlukan suatu pengembangan media pembelajaran berbasis interaktif ini dengan memanfaatkan android dalam proses pembelajaran. Hal ini dimaksudkan untuk memberikan inovasi pembelajaran pada mata kuliah fisika sehingga mahasiswa memiliki motivasi yang tinggi terhadap mata kuliah fisika. Penelitian dilakukan di Program Studi Teknik Informatika, Fakultas Teknik, Universitas PGRI Madiun Tahun Pelajaran 2016/1017. Data yang diperoleh adalah data kuantitatif dan data kualitatif. Data kuantitatif berupa nilai rata-rata dari angket. Angka tersebut kemudian dianalisis rata-rata sehingga dapat disimpulkan tingkat kelayakan Media pembelajaran. Sedangkan data kualitatif berupa tanggapan, kritik, dan saran dari ahli dan pengguna. Saran, kritik, dan tanggapan digunakan sebagai pertimbangan dalam melakukan revisi terhadap media pembelajaran. Hasil penelitian menunjukkan bahwa media pembelajaran yang dikembangkan masuk dalam kriteria layak. Hal ini ditunjukkan dengan nilai rata-rata dari validasi ahli materi 3,3; ahli media 3,3; dan pengguna 3,4. Hasil tersebut masuk dalam kriteria layak.
\end{abstract}

Kata kunci: pembelajaran fisika, media pembelajaran, dan multimedia

\section{PENDAHULUAN}

Fisika merupakan suatu cabang ilmu pengetahuan sains. Fisika mempelajari tentang sesuatu yang konkret dan dapat dibuktikan secara matematis. Pada dasarnya pembelajaran fisika perlu disesuaikan dengan cara fisikawan terdahulu dalam memperoleh pengetahuan. Oleh karena itu, dalam pembelajaran fisika harus diarahkan untuk mencari tahu dan berbuat sehingga dapat membantu maha-siswa untuk memperoleh penguasaan konsep yang lebih mendalam.

Pada umumnya, mahasiswa memiliki persepsi kurang baik tentang mata kuliah Fisika. Tidak sedikit dari mahasiswa yang beranggapan bahwa mata kuliah fisika itu sulit dan menakutkan. Oleh karena itu, anggapan negatif ini perlu dihilangkan dan perlu diubah pola pikir mahasiswa tentang anggapan negatif ini. Walaupun selama ini pembelajaran mata kuliah fisika sudah memanfaatkan teknologi, tetapi belum pemanfaatan ini belum optimal.

Untuk itu, diperlukan suatu pengembangan media pembelajaran pada mata kuliah fisika yang tepat untuk mengubah pola pikir mahasiswa. Pemilihan media pembelajaran sesuai dengan karakteristik mata kuliah dan tujuan dari pembelajaran. Ketepatan dalam pemilihan media berpengaruh terhadap hasil belajar dan keberhasilan mahasiswa mengikuti pembelajaran perkuliahan tersebut (Sriyanti, I. 2009).

Berdasarkan hasil pengalaman saat mengajar di kelas, penyebab rendahnya hasil belajar mata kuliah fisika, salah satu dikarenakan kurangnya penggunaan pem-belajaran berbasis multimedia interaktif. Teknologi informasi dapat digunakan untuk mengembangkan model pembel-ajaran. Salah satu keuntungan yang dapat diperoleh melalui pemanfaatan android sebagai media dalam pembelajaran adalah mahasiswa mampu memahami konsep secara mendalam. Beberapa peneliti pendidikan menyatakan bahwa teknologi sangat potensial untuk meningkatkan kualitas pembelajaran. (Liao, 1992).

Penggunaan media secara kreatif dapat memperlancar dan meningkatkan efesiensi pembelajaran sehingga tujuan 
pembelajaran dapat tercapai. Media pembelajaran merupakan salah satu aspek penting dalam proses pendidikan, menurut Schramm dalam Sudrajat (2008) media pembelajaran adalah teknologi pembawa pesan yang dapat dimanfaatkan untuk keperluan pembelajaran. Selain itu media mempunyai berbagai manfaat antara lain yaitu membantu pengajar dalam menyampaikan materi ajarnya, media juga dipandang sebagai suatu alat komunikasi yang menjembatani antara ide-ide yang abstrak dengan dunia nyata. Penggunaan media juga membuat proses interaksi, komunikasi dan penyampaian materi antara dosen dan mahasiswa agar dapat berlangsung secara tepat dan berdaya guna. Seiring dengan berkembang-nya teknologi, dewasa ini telah tersedia berbagai macam media pembelajaran, salah satu media yang mempunyai banyak kelebihan dari media lain yaitu multimedia komputer karena setiap informasi yang berupa tulisan, audio, dan gambar dapat ditunjukkan secara bersamaan. Beberapa penelitian menunjukkan, bahwa penggunaan multimedia interaktif mampu meningkatkan penguasaan konsep (Ferawati, 2011), prestasi belajar (Prastika, dkk, 2015), dan kemampuan berpikir kritis (Wiyono, dkk, 2009).

Berdasarkan hasil pengalaman dan evaluasi terhadap rendahnya hasil belajar mahasiswa pada matakuliah Fisika dapat disebabkan oleh: (1) Model pembelajaran konvensional yang mengakibatkan maha-siswa bersifat pasif dan menghafalkan fakta-fakta, konsep, prinsip, hukum dan rumus. (2) Adanya miskonsepsi dan kondisi pembelajaran yang kurang mem-perhatikan prakonsepsi yang dimiliki mahasiswa. Selain itu, rendahnya hasil belajar mata kuliah fisika juga diduga karena kurangnya penggunaan media pembelajaran inovatif dan interaktif.

Berdasarkan uraian di atas, penting dilakukan penelitian yang memfokuskan pada pengembangan media pembelajaran interaktif guna meningkatkan pemahaman konsep mahasiswa. Pada penelitian ini dikembangkan pembelajaran multimedia interaktif untuk meningkatkan pemaham-an konsep mahasiswa pada mata kuliah Fisika terutama pada materi Optik dengan memanfaatkan android.

Penelitian ini bertujuan untuk mengembangkan media pembelajaran ber-basis multimedia interaktif dalam mening-katkan pemahaman konsep mahasiswa dalam mata kuliah fisika.

\section{Pembelajaran Fisika}

Fisika mempelajari struktur materi dan interaksinya untuk memahami sistem alam dan sistem buatan atau teknologi (Sutrisno, 1992:27). Fisika merupakan ilmu yang memahami aturan-aturan alam yang dapat dideskripsikan secara matematis. Matematis dalam hal ini berfungsi sebagai bahasa komunikasi sains termasuk Fisika. Keterkaitan sains dan kehidupan manusia beberapa tahun terakhir ini menunjukkan kemajuan yang pesat berkat keberhasilan manusia dalam menganalisis dan mendeskripsikan alam.

Fisika adalah bagian dari sains. Sains berasal dari kata scientia yang berarti pengetahuan. Menurut Koes $\mathrm{H}$., (2003:4) membicarakan hakikat fisika sama halnya dengan membicarakan hakikat sains karena fisika merupakan bagian yang tak terpisahkan dari sains. Oleh karena itu, karakteristik fisika pada dasarnya sama dengan karakteristik sains pada umumnya. Kaitannya dalam pembelajaran fisika, objek yang diajarkan adalah fisika. Sedangkan fisika pada dasarnya sama dengan karakteristik sains pada umumnya, maka dalam belajar fisika tidak terlepas dari penguasaan konsep-konsep dasar fisika, teori, atau masalah baru yang memerlukan jawaban melalui pemahaman sehingga ada perubahan dalam diri mahasiswa. Untuk mendapatkan suatu konsep maka diperlukan suatu cara yaitu metode ilmiah atau scientific methods.

Pembelajaran fisika merupakan proses aktif, sehingga teori kognitif digunakan sebagai dasar pijakan dalam mengembangkan pendekatan pembelajar-an fisika. Aspek pemahaman merupakan inti dari proses belajar (Santyasa, 2008). Dengan demikian, dapat dikatakan bahwa pembelajaran yang benar dapat memberikan 
pemahaman bagi mahasiswa. Secara umum, kunci utama belajar adalah dimengertinya hal-hal yang dipelajari. Lebih lanjut, fisika harus dijadikan mata kuliah yang menarik sekaligus bermanfaat bagi mahasiswa. Oleh sebab itu, pada mata kuliah fisika harus ditekankan pada pengalaman belajar secara langsung dengan penggunaan dan pengembangan kemampuan berpikirnya.

\section{Multimedia Interaktif}

Definisi multimedia beragam tergan-tung pada lingkup aplikasi serta perkembangan teknologi multimedia itu sendiri. Multimedia tidak hanya memiliki makna antara teks dan grafik sederhana saja, tetapi juga dilengkapi dengan suara, animasi, video, dan interaksi. Sambil mendengarkan penjelasan dapat melihat gambar, animasi maupun membaca penjelasan dalam bentuk teks (Sutopo, 2008). Multimedia mengkombinasi teks, seni, suara, gambar, animasi, dan video yang disampaikan dengan komputer dan dapat disampaikan secara interaktif. Hal ini sesuai dengan Suyanto (2003) yang menjelaskan multimedia adalah pemanfaatan komputer untuk membuat dan menggabungkan teks, grafik, audio, gambar bergerak (video dan animasi) dengan menggabungkan link dan tool yang memungkinkan pemakai melakukan navigasi, berinteraksi, berkreasi, dan berkomunikasi.

Menurut Vaughan (2011), terdapat tiga jenis multimedia, yaitu multimedia interaktif, multimedia hiperaktif, multimedia linear, dan multimedia. Sedangkan menurut Sigit (2008), multimedia terbagi menjadi dua kategori, yaitu: multimedia linier dan multimedia interaktif. Multimedia Interaktif merupakan suatu alat yang dilengkapi dengan alat kontrol yang dapat dioperasikan oleh penggunanya dalam memilih sesuatu yang dikehendaki. Contoh Multimedia interaktif adalah: multimedia pembelajaran inter-aktif (pembelajaran berbasis multimedia interaktif), aplikasi game dan lain-lain.

\section{Model Pembelajaran Berbasis}

Multimedia Interaktif

Pada dasarnya, pembelajaran diselenggarakan dengan harapan agar mahasiswa mampu menangkap/menerima, memproses, menyimpan, serta mengelu-arkan informasi yang telah diolahnya. Media yang dapat mengakomodir persyaratanpersyaratan tersebut adalah komputer. Komputer mampu menyajikan informasi yang dapat berbentuk video, audio, teks, grafik, dan animasi (simulasi). Sebagai contoh, pada pembelajaran matematika, beberapa topik yang sulit disampaikan secara konvensional atau sangat membutuhkan akurasi yang tinggi, dapat dilaksanakan dengan bantuan teknologi komputer/ multimedia, seperti grafik dan diagram dapat disajikan dengan mudah dan cepat, penampilan gambar, warna, visualisasi, video, animasi dapat mengoptimalkan peran indra dalam menerima informasi ke dalam sistem informasi (Kariadinata, 2010). Berdasarkan penjelasan tersebut dapat ditarik kesimpulan bahwa pembelajaran berbasis multimedia adalah pembelajaran yang menggunakan bantuan komputer/ multimedia dengan memanfaatkan android.

Menurut Nandi (2006), terdapat beberapa format sajian pembelajaran berbasis multimedia Interaktif seperti berikut: 1) Model tutorial merupakan salah satu model pembelajaran interaktif yang digunakan dalam proses belajar mengajar dengan menggunakan software berupa program komputer berisi materi mata kuliah. Tutorial dalam program multimedia interaktif ditujukan sebagai pengganti manusia sebagai instruktur pada kenyataannya, 2) Model Drills merupakan salah satu bentuk model pembelajaran interaktif berbasis komputer (CBI) yang bertujuan memberikan pengalaman belajar yang lebih kongkret melalui penyediaan latihan-latihan soal untuk menguji penampilan siswa melalui kecepatan menyelesaikan soal yang diberikan program, 3) Model simulasi pada dasarnya merupakan salah satu strategi pembelajaan yang bertujuan memberikan pengalaman secara nyata melalui penciptaan tiruan bentuk pengalaman yang mendekati suasana sebenarnya dan berlangsung dalam suasana yang tanpa resiko, dan 4) Model Instructional Games adalah salah satu model pembelajaran dengan menggunakan multimedia 
interaktif berbasis komputer. Tujuan Model Instructional Games adalah untuk menye-diakan suasana atau lingkungan yang memberikan fasilitas belajar yang menambah kemampuan siswa. Model Instructional game ini tidak perlu menirukan hal nyata namun memiliki karakter tertentu bagi siswa.

Berdasarkan penelitian yang

dilaku-kan oleh Ferawati (2011), Model pembelajaran multimedia Interaktif dapat meningkatkan penguasaan konsep guru-guru fisika. Selain itu, didukung pula dengan hasil penelitian Sriyanti (2012) yang memanfaatkan multimedia pada pembelajaran Model Blended elearning juga mampu hasil belajar mahasiswa. Penelitian lain juga menunjukkan jika pengembangan pembelajaran multimedia interaktif mampu meningkatkan penguasaan konsep mahasiswa (Gunawan, dkk, 2014). Dari kedua penelitian tersebut, terlihat jelas bahwa pembelajaran multimedia interaktif memberikan manfaat pada pembelajaran. Pada pembelajaran multimedia interaktif, mahasiswa dapat mempelajari materi tertentu secara mandiri dengan menggunakan komputer yang dilengkapi dengan program berbasis multimedia (Kadir dan Triwahyuni, 2003).

\section{METODE PENELITIAN}

Penelitian dilakukan di Program studi Teknik Informatika, Fakultas Teknik, Universitas PGRI Madiun Tahun Pelajaran 2016/1017.

Rancangan penelitian ini merupakan penelitian pengembangan yang dimaksudkan untuk memperoleh suatu produk media pembelajaran. Menurut Borg dan Gall (1989) dalam Koes H. (2008:21), penelitian pengembangan dilakukan melalui sepuluh langkah pokok yang merupakan siklus pengembangan untuk menghasilkan produk pendidikan. Tetapi dalam penelitian ini, langkah tersebut disederhanakan menjadi 5 langkah. Kelima langkah tersebut adalah (1) mengumpulkan informasi dan penelitian, (2) perencanaan, (3) pengem-bangan bentuk awal produk, (4) uji lapangan awal, (5) revisi produk utama.

Data yang diperoleh adalah data kuantitatif dan data kualitatif. Data kuantitatif berupa nilai rata-rata dari angket. Angka tersebut kemudian dianalisis rata-rata sehingga dapat disimpulkan tingkat kelayakan Media pembelajaran. Sedangkan data kualitatif berupa tanggapan, kritik, dan saran dari ahli dan pengguna. Saran, kritik, dan tanggapan digunakan sebagai pertimbangan dalam melakukan revisi terhadap media pembelajaran.

Data yang diperoleh dari validasi oleh ahli materi, ahli materi, dan uji pengguna akan dianalisis dengan teknik analisis rata-rata. Dari nilai rata-rata yang diperoleh, kemudian ditentukan tingkat kelayakan media pembelajaran yang dikembangkan. Penentuan teknik analisis nilai rata-rata berdasarkan pendapat dari Arikunto (2002:216) yang menyatakan bahwa untuk mengetahui peringkat nilai akhir pada setiap butir angket penilaian, jumlah nilai yang diperoleh dibagi dengan banyaknya responden yang menjawab angket penilaian tersebut. Berdasarkan pendapat tersebut, rumus untuk menghitung nilai rata-rata adalah sebagai berikut.

$$
\bar{X}=\frac{\sum x}{n}
$$

Ket.: $\quad \begin{aligned} \bar{X} & =\text { Nilai rata-rata } \\ \sum_{\mathrm{n}} x & =\text { Jumlah skor jawaban penilaian } \\ & =\text { Jumlah penilai }\end{aligned}$

Untuk memperkuat data hasil penilaian, dikembangkan jenjang kualifikasi kriteria kelayakan. Pada penelitian ini, skala penilaian yang digunakan adalah 1 sampai 4, dimana 1 sebagai nilai terendah dan 4 sebagai nilai tertinggi. Penentuan rentang dapat diketahui melalui rentang nilai tertinggi dikurangi nilai terendah dibagi dengan nilai tertinggi. Berdasarkan penentuan rentang tersebut diperoleh rentang 0,75. Adapun kriteria kelayakan analisis ratarata yang digunakan dapat dilihat pada Tabel 3.1. 
Tabel 3.1 Kriteria Kelayakan Analisis Nilai Rata- rata

\begin{tabular}{ll}
\hline Rata- rata & Kategori \\
\hline $3,26-4,00$ & Layak \\
$2,51-3,25$ & Cukup Layak \\
$1,76-2,50$ & Kurang layak \\
$1,00-1,75$ & Tidak layak \\
\hline \multicolumn{2}{l}{ (Diadaptasi dari Arikunto, 2002) }
\end{tabular}

\section{HASIL}

Pengembangan perangkat lunak dibangun dengan aplikasi Adobe flash CS 6 dengan bahasa pengembangan Air for Android. Kebutuhan yang diperlukan untuk mendukung pembuatan media pembelajaran ini sebagai berikut.

1. Kebutuhan Hardware (Personal Computer): Processor AMD Quad-Core, $1.50 \mathrm{GHz}$, Random Access Memory (RAM) 2 Gb, Hard Disk 500 Gb, Keyboard dan Mouse

2. Kebutuhan Software

a. Adobe Flash CS6

Aplikasi Adobe Flash CS6 digunakan untuk membangun media pembelajaran interaktif pengenalan alat komunikasi dengan menggunakan bahasa pemrograman Air for Android.

b. CorelDraw X4

CorelDraw X4 digunakan sebagai apli-kasi pendukung dalam pembuatan dan editing desain gambar secara vektor yang diperlukan dalam pembuatan media pembelajaran interaktif.

c. Adobe Photoshop CS6

Adobe Photoshop CS6 digunakan seba-gai aplikasi pendukung dalam editing desain gambar yang diperlukan dalam pembuatan media pembelajaran interaktif.

Adapun User Interface aplikasi adalah sebagai berikut.

a. Halaman Pembuka

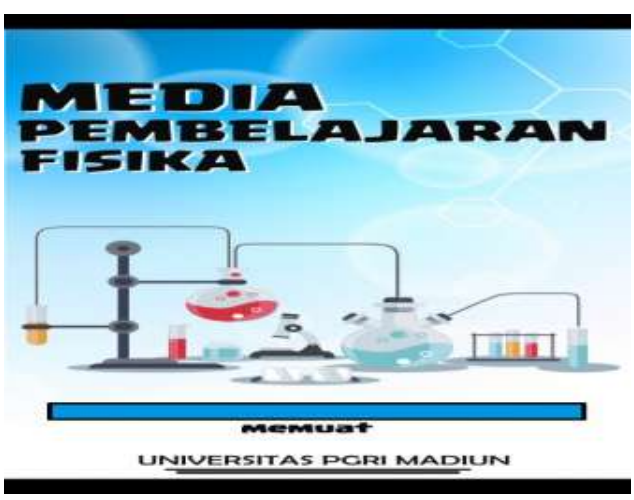

b. Halaman Menu Utama

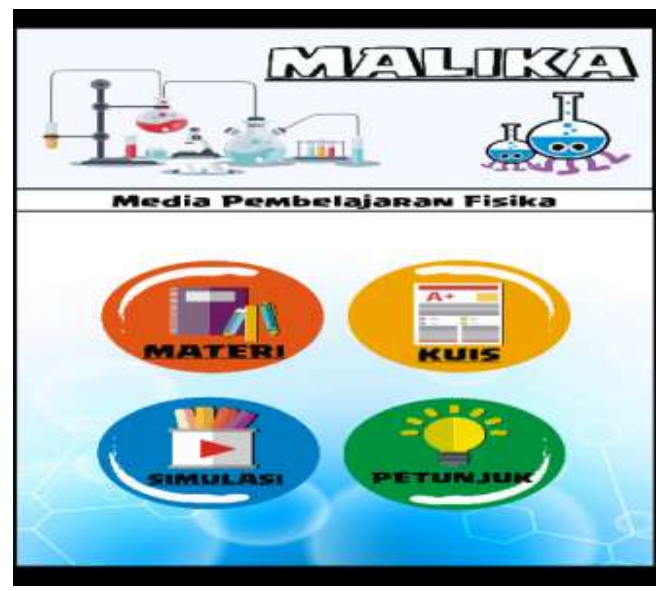

c. Halaman Petunjuk

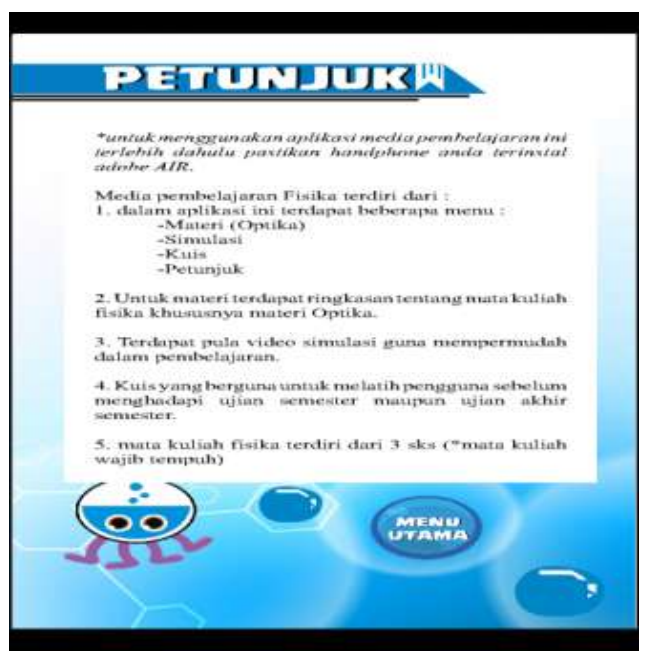

d. Halaman Materi

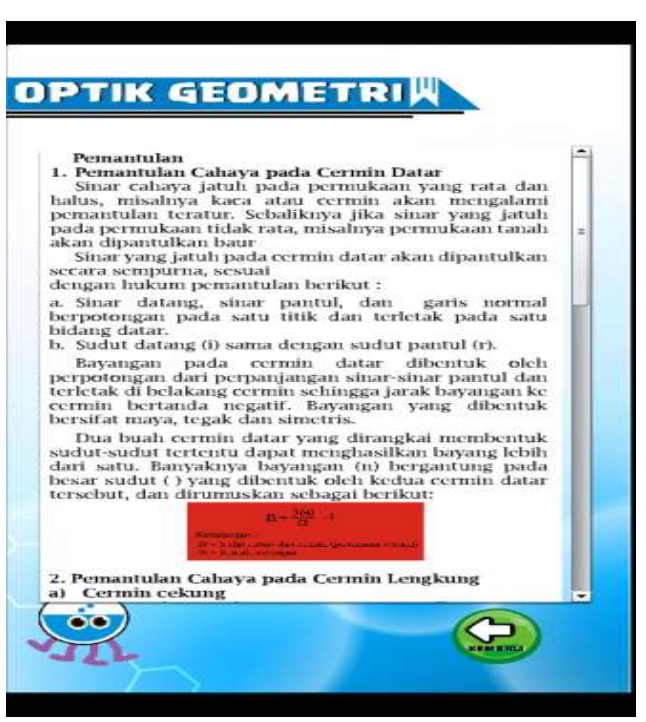




\section{e. Halaman Simulasi}

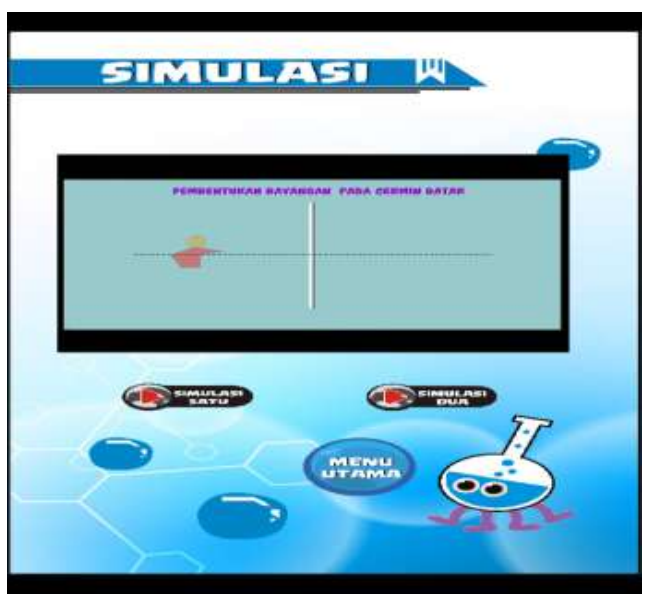

f. Halaman Kuis
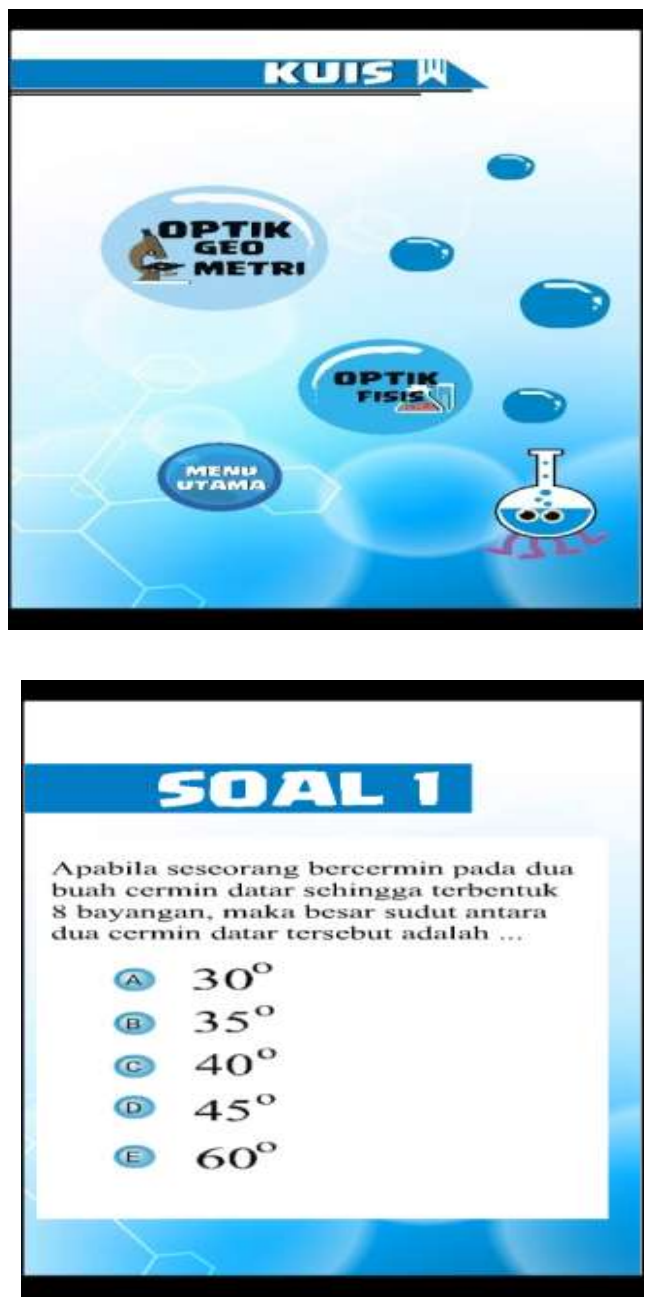

Validasi produk media pembelajaran dilakukan oleh ahli materi dan ahli media. Ahli materi terdiri dari 1 orang dan ahli media terdiri dari 3 orang.
Hasil validasi dari ahli materi diperoleh data kuantitatif yang menunjukkan bahwa media pembelajaran dalam aspek kelayakan isi termasuk dalam kriteria layak (3,3). Hasil perhitungan aspek kelayakan isi dapat dilihat pada tabel 4.1. Selain itu, didapatkan juga informasi dari ahli materi yaitu:

a. Soal materi terlalu banyak

b. Penulisan rumus kurang rapi

c. Penambahan rumus yang kurang Dari catatan tersebut dilakukan revisi ulang seperti yang disarankan oleh ahli materi. Selanjutnya media pembelajaran ini mendapatkan rekomendasi untuk dilakukan ujiboca terbatas kepada mahasiswa.

Tabel 1 Penilaian Aspek Kelayakan Isi Media Pembelajaran

\begin{tabular}{|c|c|c|c|}
\hline No & Aspek yang dinilai & V4 & Ket. \\
\hline 1 & $\begin{array}{l}\text { Materi yang disajikan sesuai dengan } \\
\text { kebenaran fakta, konsep, prinsip, } \\
\text { dan teori fisika dan tidak } \\
\text { menimbulkan banyak tafsir. }\end{array}$ & 4 & Layak \\
\hline 2 & $\begin{array}{l}\text { Ilustrasi disajikan dengan ukuran } \\
\text { dan bentuk yang proporsional serta } \\
\text { dilengkapi dengan keterangan- } \\
\text { keterangan yang tepat. }\end{array}$ & 3 & $\begin{array}{l}\text { Cukup } \\
\text { Layak }\end{array}$ \\
\hline 3 & $\begin{array}{l}\text { Materi yang disajikan mengkaitkan } \\
\text { materi fisika dengan lingkungan, } \\
\text { perkembangan teknologi dan } \\
\text { aplikasinya dalam kehidupan } \\
\text { sehari-hari. }\end{array}$ & 3 & $\begin{array}{l}\text { Cukup } \\
\text { Layak }\end{array}$ \\
\hline 4 & $\begin{array}{l}\text { Konsep dasar atau sederhana } \\
\text { disajikan terlebih dahulu sebelum } \\
\text { konsep yang lebih rumit. }\end{array}$ & 3 & $\begin{array}{l}\text { Cukup } \\
\text { Layak }\end{array}$ \\
\hline 5 & $\begin{array}{l}\text { Penyajian materi bersifat interaktif } \\
\text { dan partisipatif sehingga } \\
\text { memotivasi mahasiswa untuk } \\
\text { belajar mandiri. }\end{array}$ & 3 & $\begin{array}{l}\text { Cukup } \\
\text { Layak }\end{array}$ \\
\hline 6 & $\begin{array}{l}\text { Berbagai jenis ilustrasi untuk } \\
\text { mendukung materi yang disajikan }\end{array}$ & 3 & $\begin{array}{l}\text { Cuku } \\
\text { p } \\
\text { Layak }\end{array}$ \\
\hline 7 & $\begin{array}{l}\text { Pendahuluan disajikan dengan } \\
\text { sederhana dan lugas. }\end{array}$ & 4 & Layak \\
\hline 8 & $\begin{array}{l}\text { Mengarahkan penggunaan } \\
\text { smartphone ke arah yang lebih } \\
\text { positif }\end{array}$ & 4 & Layak \\
\hline & Nilai Rata-rata total & 3,3 & Layak \\
\hline
\end{tabular}

Hasil validasi dari ahli media diperoleh data kuantitatif yang menunjukkan bahwa media pembelajaran dalam aspek kelayakan media termasuk dalam kriteria layak $(3,3)$. Hasil perhitungan aspek kelayakan isi dapat dilihat pada tabel 4.2. Selain itu, didapatkan juga informasi dari ahli media yaitu:

a. Halaman pembuka diperbaiki, agar lebih menarik 
b. Tutorial dilengkapi

c. Ukuran font rumus dibuat lebih menarik

d. Tombol scroll dan back diperbaiki

Dari catatan tersebut dilakukan revisi ulang seperti yang disarankan oleh ahli media. Selanjutnya media pembelajaran ini dilakukan uji coba terbatas kepada mahasiswa.

\begin{tabular}{|c|c|c|c|c|c|c|c|}
\hline $1 \mathrm{a}$ & & $\begin{array}{l}\text { Penilaian Aspek } \\
\text { Pembelajaran }\end{array}$ & & & kar & & dia \\
\hline $\begin{array}{l}\mathrm{N} \\
\mathrm{O}\end{array}$ & & dinilai & & & & $\begin{array}{l}\text { Rata- } \\
\text { rata }\end{array}$ & Ket. \\
\hline 1 & $\begin{array}{l}\text { Apl } \\
\text { pen } \\
\text { den } \\
\text { dip }\end{array}$ & $\begin{array}{l}\text { lkasi media } \\
\text { belajaran relevan } \\
\text { gan materi yang } \\
\text { lajari mahasiswa }\end{array}$ & 4 & 3 & 3 & 3,3 & Layak \\
\hline 2 & $\begin{array}{l}\text { Apl } \\
\text { pen } \\
\text { dig } \\
\text { pen } \\
\text { kel } \\
\text { kel }\end{array}$ & $\begin{array}{l}\text { lkasi media } \\
\text { abelajaran dapat } \\
\text { anakan untuk } \\
\text { abelajaran individu, } \\
\text { mpok kecil, dan } \\
\text { mpok besar }\end{array}$ & 2 & 3 & 4 & 3,0 & $\begin{array}{l}\text { Cukup } \\
\text { Layak }\end{array}$ \\
\hline 3 & $\begin{array}{l}\text { Apl } \\
\text { pen } \\
\text { mel } \\
\text { mu }\end{array}$ & $\begin{array}{l}\text { lkasi media } \\
\text { lbelajaran } \\
\text { gggunakan bahasa yang } \\
\text { lah dipahami }\end{array}$ & 3 & 3 & 3 & 3,0 & $\begin{array}{l}\text { Cukup } \\
\text { Layak }\end{array}$ \\
\hline 4 & $\begin{array}{l}\text { Apl } \\
\text { pen } \\
\text { mat }\end{array}$ & $\begin{array}{l}\text { asi media } \\
\text { elajaran membuat } \\
\text { i mudah diingat }\end{array}$ & 4 & 3 & 3 & 3,3 & Layak \\
\hline 5 & $\begin{array}{l}\text { Soa } \\
\text { pad }\end{array}$ & $\begin{array}{l}\text { ngacu } \\
\text { g disajikan }\end{array}$ & 3 & 3 & 4 & 3,3 & Layak \\
\hline 6 & & $\begin{array}{l}\text { lasan petunjuk } \\
\text { ggunaan }\end{array}$ & 3 & 3 & 3 & 3,0 & $\begin{array}{l}\text { Cukup } \\
\text { Layak }\end{array}$ \\
\hline 7 & & $\begin{array}{l}\text { suaian warna tampilan } \\
\text { ackground }\end{array}$ & 4 & 4 & 3 & 3,7 & Layak \\
\hline 8 & $\begin{array}{l}\text { Mer } \\
\text { kon } \\
\text { mel }\end{array}$ & $\begin{array}{l}\text { u dan tombol } \\
\text { sisten dan tidak } \\
\text { ggangu tampilan }\end{array}$ & 3 & 3 & 4 & 3,3 & Layak \\
\hline 9 & $\begin{array}{l}\text { Seti } \\
\text { den } \\
\text { pro }\end{array}$ & $\begin{array}{l}\text { bagian terhubung } \\
\text { an baik sehingga } \\
\text { am tampak jelas }\end{array}$ & 3 & 4 & 3 & 3,3 & Layak \\
\hline $\begin{array}{l}1 \\
0\end{array}$ & $\begin{array}{l}\text { Mer } \\
\text { smi } \\
\text { lebi }\end{array}$ & $\begin{array}{l}\text { arahkan penggunaan } \\
\text { tphone ke arah yang }\end{array}$ & 3 & 4 & 4 & 3,7 & Layak \\
\hline & $\mathrm{Ni}$ & a total & & & 4 & 3,3 & Layak \\
\hline
\end{tabular}

Selain, validasi dilakukan pada ahli media dan ahli materi, juga dilakukan validasi pada mahasiswa. Mahasiswa yang digunakan sebanyak 12 mahasiswa. Hal ini, dilakukan untuk mengetahui tingkat kelayakan pengguna dan segi keterbacaan. Hasil validasi dari pengguna, didapatkan nilai kuantitatif sebesar 3,4 dengan kriteria layak.

Media pembelajaran merupakan salah satu aspek penting dalam proses pendidikan, menurut Schramm dalam Sudrajat (2008) media pembelajaran adalah teknologi pembawa pesan yang dapat dimanfaatkan untuk keperluan pembelajar-an. Hal ini sejalan dengan hasil penelitian ini, bahwa media pembelajaran ini layak untuk digunakan dalam pembelajaran.

\section{PENUTUP}

Kesimpulan

Berdasarkan hasil analisis dan pembahasan, dapat disimpulkan bahwa media pembelajaran berbasis multimedia interaktif telah dinilai layak secara teoritis.

\section{Saran}

Hasil penelitian ini belum memenuhi kebutuhan dan tujuan penelitian yang sebenarnya sehingga perlu dilakukan uji lapangan utama untuk mengetahui keefektifan media pembelajaran yang dikembangkan. Selain itu, perlu diadakan penelitian yang mengembangkan seluruh materi ajar dalam 1 semester dan pada sampel yang lebih luas. Sehingga dapat menghasilkan bahan ajar yang lebih baik.

\section{DAFTAR PUSTAKA}

Arikunto, Suharsimi. 2002. Prosedur Penelitian Suatu Pendekatan Praktek. Jakarta: Rineka Cipta.

Ferawati. 2011. Model Pembelajaran Multimedia Interaktif untuk Meningkatkan Penguasaan Konsep dan Keterampilan Generik Sains Guru Fisika pada Topik Fluida Dinamis. Proseding Penelitian Bidang IImu Eksakta 2011, (2011),hal: 1-10

Gunawan, dkk. 2014. Penggunaan Multimedia Interaktif dalam Pembelajaran Fisika dan Implikasinya pada Penguasaan Konsep Mahasiswa. Jurnal Pijar MIPA, Vol. IX No.1, hal: 15 - 19.

Kadir, A dan Triwahyuni.(2003). Teknologi Informasi.Yogyakarta : Kanisius.

Kariadinata, R. 2010. Kemampuan Visualisasi Geometri Spasial Siswa Madrasah Aliyah Negeri (Man) Kelas $X$ Melalui Software Pembelajaran Mandiri. Jurnal Pendidikan Fisika. Volume I, No. 2, hal: 1-13

Koes H., Supriyono. 2003. Strategi Pembelajaran Fisika. Malang: Jurusan Pendidikan Fisika, FMIPA, Universitas Negeri Malang. 
Koes H., Supriyono, Prasetyo, Triastono $\begin{array}{lr}\text { I., dan Parlan. } & 2008 . \\ \text { Pengembangan } & \text { Paket IPA } \\ \text { Terpadu rrasis } \\ \text { Konstruktivisme r } & \text { Berbasis untuk } \\ \text { Meningkatkan Kompetensi IPA } \\ \text { Siswa. Malang: Universitas } \\ \text { Negeri Malang. }\end{array}$

Liao, Y.K. 1992. Effects of Computerassisted Intruction on Cognitive Outcomes : A Meta Analysis. Journal of Research on Computing in Education, 24

Nandi, 2006. Penggunaan Multimedia Interaktif Dalam Pembelajaran Di Persekolahan. Jurnal "GEA" Jurusan Pendidikan Geogarafi Vol.6, No.1, April 2006.

Prastika, L. R., dkk. 2015. Pengaruh Penggunaan Multimedia Interaktif Berbasis Komputer Model Instructional Games terhadap Peningkatan Prestasi Belajar Siswa pada Mata Pelajaran Fisika. Prosiding Simposium Nasional Inovasi Pembelajaran dan Sains 2011 (SNIPS 2015) Bandung, (2015): hlm 397-400.

Santyasa, I.W. (2008). Pengembangan Pemahaman Konsep dan Kemampuan Pemecahan Masalah Fisika Bagi Siswa SMA dengan Pemberdayaan Model Perubahan Konseptual Berseting Investigasi Kelompok. Diakses dari http://www.infodiknas.com/wpcontent/uploads/2014/10/PENGE MBANGAN-PEMAHAMAN-KONSEPDAN-KEMAMPUAN-PEMECAHANMASALAH-FISIKA-BAGI-SISWASMA-DENGAN-PEMBERDAYAANMODEL-PERUBAHANKONSEPTUAL-BERSETINGINVESTIGASI-KELOMPOK.pdf
Sriyanti, I. 2009. M-Learning : Alternatif Media Pembelajaran di LPTK. Makalah Seminar Nasional Pendidikan(http://eprints.unsri.ac. id/2223/1/M._leaning)

Sudrajat, Akhmad. 2008. Media Pembelajaran.(online). (http://akhmadsudrajat. wordpress.com/2008/01/12/kons ep-media-pembelajaran/). Diakses 1 Mei 2016.

Sutopo, Hadi. 2008. Pengembangan Bahan Ajar Berbasis Multimedia. Tersedia http://www.topazart.info/teks_tea ching/mat/flash/tutorialBahanAja rMultimedia.Pdf

Sutrisno, L.1992. Konsep Awal Siswa dalam Tradisi Kontruktivis. Pontianak :FKIP UNTAN.

Suyanto, M.2003. Multimedia Alat untuk Meningkatkan Keunggulan Bersaing .Yogyakarta: Andi.

Vaughan, Tay. 2011. Multimedia: Making It Work, 8th Edition. New York: McGraw-Hill

Wiyono, K., dkk. 2009. Model Pembelajaran multimedia Interaktif Relativitas Khusus untuk Meningkatkan Keterampilan Berpikir Kritis Siswa SMA. Makalah Seminar Nasional Pendidikan di FKIP Universitas Sriwijaya Palembang, (2009): hal: 1-12. 